\title{
INDEMNIFICATION OF INSIDERS' LITIGATION EXPENSES
}

\author{
George T. Frampton*
}

Litigation expenses are borne cheerlessly at best. All the less bearable are they when charged to the "wrong" party. If such a mischarge could be prevented by a simple formula whenever corporate insiders ${ }^{1}$ are involved in litigation arising from management of the business, the common law well might have found that formula; and statutory modifications, where necessary at all, could have been brief, uniform, and satisfactory.

But determining whether a particular litigation expense is a legitimate cost of the business or a personal risk of the insider-defendant requires consideration of a variety of possible circumstances. Neither the common law nor most of the twentyfour statutory enactments of the last sixteen years have given due recognition to the relevance of these circumstances, nor have they agreed on whether the courts or the directors themselves should make the determination.

These circumstances and their interrelated bearing on the propriety of indemnity are suggested by four general questions:

First, what was the nature of the litigation? It may have been an action in which the corporation was the plaintiff, either on its own initiative or in an action brought derivatively by its shareholders or creditors. It may have been brought by private parties, hostile to the corporation, against the corporation and the insiders to enforce a private right or a public policy. It may have been initiated by shareholders in the course of a proxy contest to test the validity of corporate practices or procedures allegedly giving an unfair advantage to insiders in the contest. ${ }^{2}$ Or it may have been a government proceeding, civil or criminal, against the corporation and its insiders to exact a fine or otherwise penalize or enjoin corporate conduct or practices initiated or approved by the insiders.

Second, what was the nature of the act or conduct complained of? It may have

*A.B. I938, LL.B. I94I, Duke University. Member of the New York and Illinois bars; Professor of Law, University of Illinois.

${ }^{2}$ Most statutes now define "insiders" to include former, present, and future directors and officers of the corporation and also persons who may have been requested by the corporation to serve as directors or officers of another corporation in which the corporation has an interest.

${ }^{2}$ Litigation of this type has arisen out of all the following recent proxy contests in widely-held corporations: American Woolen (Textron, Inc. v. American Woolen Co., 122 F. Supp. 305 (E.D. Mass. I954)); New York Central (Schildkret v. Ebbott, 148 N.Y.S.2d 678 (Sup. Ct.), aff'd, 1 App. Div. $2 d$ 879, 150 N.Y.S.2d 773 (1st Dep't 1956) (action by Young and Kirby against insiders before the election of directors was consolidated with other actions brought after the election)); Montgomery Ward (Wolfson v. Avery, 6 Ill.2d 78, 126 N.E.2d 7or (r955)); Fairbanks-Morse (Penn-Texas Corp. v. Morse, 242 F.2d 243 (7th Cir. 1957)); Loew's (Tomlinson v. Loew's, Inc., 134 A.2d 518, aff'd, I35 A.2d 136 (Del. Ch. 1957)); Campbell v. Loew's, Inc., 134 A.2d 852 (Del. Ch. 1957)). 
been such that the defendant knew or ought to have known that it was wrong. Or it may have been such that he could not fairly be charged with foreseeing the possibility that it would be alleged or found to be unlawful.

Third, what was the disposition of the action? The insiders may have been wholly vindicated by judgment or dismissal on the merits. The action may have been terminated by the litigative process unfavorably for either party otherwise than on the merits. Or part of what the plaintiff sought may have been granted, the rest refused. Most likely, considering the small proportion of actions that ever proceed to final judgment, it was settled. The settlement may have obviated any judicial pronouncement on the merits. Or it may have been effected, after a verdict or judgment for or against the insiders, to avoid an appeal.

Finally, what was the relationship between "ownership" and insider-management in this corporation, and, in the light of that relationship, what internal action was taken or procedure followed regarding both the act or conduct complained of and the act of indemnification itself? As to the act complained of, the shareholders may have approved it. As to indemnification, they may have voted specifically that the corporation assume the expense of defending the act complained of. In either case, the disinterestedness of the assenting shareholders is relevant. And if they have not voted, the question remains whether there are interests to be protected against the particular indemnity and whether the corporate procedures usually prescribed for the protection of those interests when analogous corporate decisions are made have been followed in the decision to indemnify.

By 1941, scarcely more than twenty major cases and no statutes dealt with indemnification of directors for litigation expenses. With few exceptions, ${ }^{3}$ the cases arose out of shareholders' derivative actions in which wrongdoing by insiders was alleged and a money recovery for the corporation was the principal relief sought.

These pre-statute cases, in their inattention to the relevance of the circumstances suggested above or in their failure, when they did refer to the circumstances, to state meaningful criteria for weighing them, set the stage for statutory action. Although the corporation realized recoveries in many of the derivative actions, so that the courts were able to come rather easily to the conclusion that indemnification for litigation fees should not be allowed to the unsuccessful defendants, ${ }^{4}$ the courts

\footnotetext{
${ }^{8}$ Jesse v. Four Wheel Drive Auto Co., 177 Wis. 627,189 N.W. 276 (1922); Albrecht, Maguire \& Co., Inc. v. General Plastics, Inc., 256 App. Div. 134, 9 N.Y.S.2d 415 (4th Dep't 1939). In Mason v. Pcwabic Min. Co., 66 Fed. 39r (6th Cir. 1894), plaintiffs asked not for a money accounting, but for dissolution of the corporation and distribution of its assets in lieu of a plan of defendants for sale of assets and continuation of the business. See also note $\mathrm{I}_{4}$ infra.

"Mason v. Pewabic Min. Co., supra note 3; Wickersham v. Crittenden, ro6 Cal. 329, 39 Pac. 603 (1895); McConnell v. Combination Mining \& Milling Co., 3I Mont. 563, 572, 79 Pac. 248, 251 (1905); McCourt v. Singers-Bigger, 145 Fed. 103 (8th Cir. 1906); Chabot \& Richard Co. v. Chabot, I09 Mc. 403, 84 Atl. 892 (I912); Hooker, Corser and Mitchell Co. v. Hooker, 88 Vt. 335, 92 Atl. 443 (1914); Brock v. Automobile Livery \& Sales Co., I37 La. 9, 68 So. 195 (1915); General Mortgage and Loan Corp. v. Guaranty Mortgage and Securities Corp., 264 Mass. 253, 162 N.E. 319 (r928); Apfel v. Auditorc, 223 App. Div. 457, 228 N.Y. Supp. 489 (Ist Dep't 1928); Monahan v. Kenny, 248 App. Div. 159, 288 N.Y. Supp. 323 (Ist Dep't 1936); Atwater v. Elkhorn Valley Coal-Land Co., $x 84$ App. Div. 253, 258-59, 17r N.Y. Supp. 552, 556 (Ist Dep't 1918) (dictum), aff'd, 227 N.Y. 611, 125 N.E. 912 (1919).
} 
did not say that indemnity would be denied only when defendants had been unsuccessful. Neither did they say that success by defendants in derivative actions would bring indemnity; nor, where they granted indemnity to defendants who had been wholly or partly successful, ${ }^{5}$ that it was based on success. They instead talked about whether counsel had actually represented the individual defendants or the corporation. This led them to inquire whether the corporate defendant had "interests" to be protected that would require representation or whether it had any "benefit" to receive from representation; and they concluded when plaintiffs won substantial victories that the corporation was neither represented nor benefited by defendants' counsel. ${ }^{\circ}$ This test, of course, ignores the question whether the defense of the individual, even when the corporation is not "directly" represented, cannot in some cases be a proper cost of the business. This test would also lead to the conclusion that indemnity is as inappropriate when the insider in a derivative action is wholly successful in his defense as when he is unsuccessful.

This test, moreover, led to a misconception so persistent in the cases that it has misshaped some of the statutes. The courts said that in the absence of a "benefit" to the corporation in the defense, there was an absence of "power" in the corporation to indemnify. This "power" argument was used, inappropriately, in cases where insiders sought indemnity against a corporation unwilling to grant it. ${ }^{7}$ The "power" of the corporation, therefore, was not at issue in those cases. While an absence of benefit in the defense itself may be a logical reason for refusing to find a right to indemnity against an unwilling corporation, the power of a willing corporation to make indemnity could be based on benefits to the corporation quite beyond the value to it of the immediate defense. The growing need of corporations to improve their relationships with their employees, management and otherwise,

EEsposito v. Riverside Sand \& Gravel Co., 287 Mass. I85, I9I N.E. 363 (1934); Solimine v. Hollander, 129 N.J. Eq. 264, I9 A.2d 344 (Ch. I94I).

- Wickersham v. Crittenden, I06 Cal. 329, 330, 39 Pac. 603, 603 (1895); Chabot \& Richard Co. v. Chabot, 109 Me. 403, 407, 84 Atl. 892, 894 (1912); Brock v. Automobile Livery \& Sales Co., 137 La. 9, 12, 68 So. 195, 196 (1915); General Mortgage and Loan Corp. v. Guaranty Mortgage and Securities Corp., 264 Mass. 253, 261, 264, 162 N.E. 319, 322, 323 (1918) (but finding that attorney's services did not "benefit" corporation held not to require attorney to return fees paid by corporation, because there was no finding that he "knew" his services would not benefit corporation); Apfel v. Auditore, 223 App. Div. 457, 458, 228 N.Y. Supp. 489, 490 (Ist Dept. 1928); Monahan v. Kenny, 248 App. Div. 159, I60-6r, 288 N.Y. Supp. 323, 324 (Ist Dept. 1936); Wood v. Noma Electric Corp., 96 N.Y.L.J. II2I (City Ct. r936).

${ }_{7}$ Chabot \& Richard Co. v. Chabot, supra note 6; Jesse v. Four Whel Drive Auto Co., 177 Wis. 627, 634,189 N.W. 276, 278 (1922); Griesse v. Lang, 37 Ohio App. 553, 556, I75 N.E. 222, 223 (I931) (quoting with approval the passage from the Jesse case, supra); New York Dock Co. v. McCollum, I73 Misc. ro6, I6 N.Y.S.2d 844 (Sup. Ct. 1939). The New York Dock Company was in an anomalous position on this point. The defendant directors had been successful and presumably wanted to vote indemnity but were "reluctant" to do so only because they did not know whether they could "safely" do so under the law (i.e., whether the corporation had the "power" to do so, even though willing). By agreement, a declaratory judgment was sought, and the corporation was represented by independent counsel who construed their obligation as requiring them to argue, as though representing an unwilling corporation, that if there were no automatic legal obligation to pay, a decision to pay would be beyond the corporation's powers. See Washington, Litigation Expenses of Corporate Directors in Stockholders' Strits, 4o Colum. L. REV, 43x, 442-43 (1940). 
and the emerging social role assumed by or imposed upon them by their size and influence have opened new areas in which the "power" of a corporation to act for corporate interests that are indirect and intangible is now recognized. Such interests support payments and commitments in discharge of moral obligations; for community, charitable, and educational purposes; and, more strikingly analogous to "underwriting" an employee's service-connected litigation expenses, for compensation and fringe benefits of a wide variety, including workmen's compensation insurance and payments, disability payments, pensions, stock-option plans, and sickness, medical, and rehabilitation plans and funds. ${ }^{8}$ Such interests, to be sure, might have occurred more readily to the courts had any case presented squarely the validity of an indemnity agreed to by the corporation before the litigation arose. But such a benefit, once recognized, could conceivably support an undertaking under proper circumstances after the litigation arose.

The courts, however, gave no sign of having considered that a "power" to indemnify, where the corporation was willing to undertake such an obligation, could be supported in any case by a benefit to the corporation in the form of protection of the insider against business-connected litigation costs. Thus unanalyzed, the "lack of power" doctrine barred the path to a sensible inquiry whether a particular expense was one which the corporation could at least elect to assume as a legitimate cost of doing business. And it hampered the common law in reaching a case-by-case but consistent philosophy about how the relevant circumstances in an indemnity case should be weighed.

This failure to provide workable rules in the easily-decided cases where defendants were unsuccessful in derivative actions left the courts at sea in the later cases where defendants were wholly or partly successful. In Figge v. Bergenthal, ${ }^{0}$ the earliest indemnity case arising out of a derivative action in which defendants won a partial victory on the merits, other claims having been held barred by limitations, the court allowed indemnity, but made no reference in its opinion to the weight it accorded the action of the defendant majority shareholders in voting indemnity during the trial. Thereafter, in the derivative action of Griesse v. Lang, ${ }^{10}$ in which defendants were wholly successful, indemnity was disallowed, and Figge was distinguished on the grounds that no action was taken by the Lang shareholders. ${ }^{11}$ But then, in Esposito v. Riverside Sand \& Gravel Co., ${ }^{12}$ defendants were partially successful and partially unsuccessful, and indemnity was allowed, without any reference to possible corporate action by shareholders or otherwise. To further the uncertainty, the almost wholly unsuccessful defendants in Godley $v$. Crandall \& Godley Co., ${ }^{13}$ were

\footnotetext{
${ }^{8}$ See Jervis, Corporate Agreements to Pay Directors' Expenses in Stockholders' Stits, 40 CoLvM. L. REv. Irg2, II99-200 (1940); Bishop, Current Status of Corporate Directors' Rights to Indemnification, 69 HARV. L. REV. T057, 1062 (1956).

${ }^{0}$ 130 Wis. 594, 109 N.W. 581 (r907). $\quad{ }^{10} 37$ Ohio App. 553, 175 N.E. 222 (1931).

1137 Ohio App. at 556, x75 N.E. at 223. $\quad 12287$ Mass. 185 , 191 N.E. 363 (1934).

${ }^{13}$ I53 App. Div. 697, 139 N.Y. Supp. 236 (Ist Dep't 1912), modified, 212 N.Y. I21, 105 N.E. 818 (1914); I8I App. Div. 75, I68 N.Y. Supp. 25 I (Ist Dep't 1917), aff'd, 227 N.Y. 656, 126 N.E. 908 (x920).
} 
allowed indemnity on the grounds that a receivership of the corporation as well as an accounting against the individuals had been sought and had been successfully resisted in part. ${ }^{14}$

Neither did clear rules emerge from the opinions in the cases arising out of nonderivative actions. In Jesse v. Four Wheel Drive Auto Co., ${ }^{15}$ indemnity was refused with regard to a personal action for fraud against insiders in the purchase of stock, without regard to the disposition of the action, which was pending at the time of the decision on litigation expenses, and also in disregard of a shareholders' resolution, adopted without objection, authorizing the defraying of expenses of the defense. In Albrecht Maguire \& Co. v. General Plastics, Inc., ${ }^{16}$ on the other hand, indemnity was allowed, even though plaintiffs were successful in their contention that nonassenting shareholders could not be deprived of their pre-emptive rights by an amendment to the certificate of incorporation. No action by directors or shareholders on the indemnity matter was indicated, nor was anything said about the composition of the shareholdings in relation to the purpose or effect of the issuance complained of. Indemnity was allowed, the court indicated, because the insiders "acted in good faith" and issued stock pursuant to a vote of the shareholders. ${ }^{17}$ While the results in both cases may have been justifiable, they were reached without the support of articulated rules.

${ }^{11}$ The Godley case, however, does not clearly support the proposition, for which it is frequeritly cited, that indemnity will be allowed whenever the complaint seeks a receivership as well as relief against the individuals. The Appellate Division and Court of Appeals described the complaint in the Elizabeth Godley action (1912) as alleging only wrongful payments to the directors, who were adjudged liable by the trial court, the Appellate Division, and the Court of Appeals, and who were directed to repay to the corporation more than $\$ 100,000$. The trial court also ordered defendants to repay amounts disbursed by the corporation for their litigation expenses in the action. The Appellate Division agreed that "it would seem as if the directors who were responsible for the conditions that required the action should pay such [litigation] expenses, instead of the corporation itself." I53 App. Div. at 714, X39 N.Y. Supp. at 249. The Court of Appeals modified the judgment on this point, however, because the original complaint had not sought any return of payments made for litigation expenses during the action and because there remained some uncertainty in the evidence as to the precise amount paid for such expenses by the corporation; but it did so "without prejudice . . . to the plaintiff's right to bring a new action therefor if so advised." 212 N.Y. at 137, 105 N.E. at 823. No questions of reccivership were dealt with in the Court of Appeals opinion.

In the George Godley action (1916), other wrongful payments were alleged, including counsél fees in an action not identified, but described as seeking appointment of a receiver. The George Godley action was dismissed by the Appellate Division for failure to allege demand on the corporation. By way of dictum, the court noted that the judgment under review included an item for fees paid to counsel "in resisting the appointment of a receiver." The court said that the scope of the receivership was "restricted" by the Court of Appeals and that counsel fees in such a matter were properly paid by the corporation. I8I App. Div. at 78, I68 N.Y. Supp. at 254. This language leaves a question whether the Appellate Division got confused into condoning, by dictum, the payment of fees which both it and the Court of Appeals had previously indicated should be borne by the individual defendants, in so far as they represented services performed substantially in defense of the unsuccessful defendants and only nominally in resisting a receivership, or whether fees on the receivership aspects of the Elizabeth Godley or some other case were separable from the other fees. In New York Dock Co. v. McCollum, I73 Misc. I06, I12, I6 N.Y.S.2d 844, 849 (Sup. Ct. 1939), the court rejected the argument that a benefit to the corporation results in resisting a receivership "asked for merely as an incidental matter." See Washington, supra note 7 , at $435-37$.

${ }^{2}$ I77 Wis. 627,189 N.W. 276 (1922).

${ }^{20} 256$ App. Div. 134, 9 N.Y.S.2d 415 (4th Dep't r939).

${ }^{17} 256$ App. Div. at 139,9 N.Y.S.2d at 420. 
The climax of this confusion in the common law was reached in New York Dock v. $M c$ Collum, ${ }^{18}$ in which indemnity was refused in a derivative action, even though defendants were wholly successful. The corporation was willing to pay, but was uncertain of its "power" or "right" to do so in view of the common-law language already described. The court held, without referring to the possibility of any corporate action that might validate assumption of the expenses, that there was no "right" of the insiders to be paid and no "power" in the corporation to assume the obligation in the absence of a corporate "interest." The court could find no such "interest," even in the successful defense of a derivative action.

The statutory reaction to these decisions has developed along three general lines since $194 \mathrm{I} .{ }^{10}$ The first and least reasoned of these, which is represented by the four "right" states, New York, Wisconsin, Pennsylvania, and Kentucky, was to provide that insiders have a "right" to be reimbursed under all circumstances, except only when there has been "negligence or misconduct" or an unsuccessful defense by the insiders. This reaction, like the common-law cases, fails to give adequate recognition to the different types of action that might be involved, the variety of the allegations that might be at issue, and the area of discretion in which a corporation should be left free, by whatever methods afford suitable protection to minority interests, to commit itself or not to commit itself to indemnify. This approach undertakes to prevent the possible mischarges to insiders, produced by common-law misconceptions, by charging everything to the corporation in all cases, except those that would go to final judgment and that defendants would lose.

The New York statute, which was the first indemnity statute to be enacted, confers the broadest right in one respect: the right is withheld only when the insider has been "adjudged liable for negligence or misconduct ${ }^{20}$ in the performance of his duties."21 Wisconsin withholds the right if the insider "is guilty of negligence or

${ }^{18}$ I73 Misc. 106, 16 N.Y.S.2d 844 (Sup. Ct. 1939).

10 For other analyses of the statutes, see Comments, 40 Calif. L. Rev. 104 (1952), 52 Mich. L. Rzv. ro23 (1954).

20 The word "misconduct" bears moral overtones, but has no well-understood legal connotation that would facilitate its interpretation in a case, let us say, where the insiders commit or authorize an unlawful act which they believe lawful or about the unlawfulness of which they had no thought at all. Wenster's New Internattonal Dictionary (2d ed. r950) is of little help in defining "misconduct," offering only such adjectives, equally lacking in content, as "bad," "wrong," or "improper" acts or behavior. This word, picked up from the New York statute, is now firmly embedded in most indemnity statutes. It probably came to the New York statute from a draft of a corporation bylaw prepared by corporate counsel. The bylaw proposed in April 1939, the second of 169 analyzed in Bates and Zuckert, Directors' Indemnity: Corporate Policy or Publia Policy, 20 Harv. Bus. Rev. 244, 25I (194I), wherein the phrase "wilful misconduct" is used, could be the anonymous source. The inappropriateness of the concept of "adjudgment" or "guilt" of "misconduct" is emphasized by Schwarz v. General Aniline \& Film Corp. 305 N.Y. 395, II3 N.E.2d 533 (1953), in which the statute was held to give a right to indemnity only as to civil actions, and not as to a criminal proceeding for violation of the federal antitrust laws brought jointly against the corporation and certain directors, the individuals having pleaded nolo contendere. MOder Business Corporation Act $\$ 4(0)$ was amended in 1957 to make the language of the statute expressly applicable to actions "civil or criminal."

${ }^{21}$ N.Y. GEN. CORP. LAW $\$ \$ 64-68$ inclusive. (Emphasis added.) An analysis of this statute is made by Bishop, supra note 8 . 
misconduct."22 This variation from the New York language of "adjudgment" may have been intended to deprive the insider of his right of indemnity if he had been negligent or had misconducted himself and had escaped "adjudgment" by settlement or otherwise. ${ }^{23}$ The determination of "guilt" of "negligence" or "misconduct" other than by the "adjudgment" of a court raises so many obvious difficulties, however, that it is doubtful whether the Wisconsin statute effects any practical protection against indemnifying a "guilty" insider who has avoided "adjudgment."

Since the Wisconsin statute contains no other reservations, it confers the most unqualified "right" to indemnity. Provisions in section sixty-seven of the New York statute further qualify the right to an extent not entirely clear. They provide that the court "shall" award indemnity where the defendant has been wholly or partly successful ${ }^{24}$ or where the action has been settled with approval of the court. But this language leaves open the question of whether the court may or may not confer a right to indemnity in other situations which do not amount to adjudgment for negligence or misconduct. These provisions are also susceptible to the interpretation that even on a mandatory award, the court has discretion to allow only so much of a reasonable fee as it would deem reasonable to allow under the circumstances; ${ }^{25}$ and the New York right is also made expressly subject to inconsistent shareholder action prior to accrual of the alleged cause of action and to inconsistent terms of a court-approved settlement. ${ }^{20}$

The Pennsylvania right is more clearly circumscribed than the other two. The right arises only from the "successful defense" of an action, with express discretion in the court to assess the corporation only such amount as it deems reasonable where the defendants are only partly successful or have settled with the approval of the court. 27

The Kentucky statute conditions the right where settlement has been effected on approval of the settlement by the board of directors and a "determination" by the board that the defendants were "not guilty of actual negligence or misconduct."28

"WIs. Stat. 5180.407 (1955). (Emphasis added.). For an analysis of this statute, see Note, r950 Wis. L. Rev. I57.

12 Consider, for example, Diamond v. Diamond, 307 N.Y. 263, r20 N.E.2d 819 (1954), in which defendant admitted misappropriation and diversion of funds, but successfully moved to dismiss on the grounds of acquiescence and ratification by plaintiff, who was the only other shareholder. The court thought it would be "unconscionable" to prefer one "wrongdoer" over another by letting defendant's expenses be paid by the corporation and plaintiff's not. It "escaped" from this result by ruling that the defendant had been "adjudged" liable, even though there had been no such judgment. The dissent seemed less worried about there having been no adjudgment than it did about there having been, in its opinion, no "misconduct."

24 "Successful," as used here, has been interpreted not to require success on the merits. Indemnity was allowed in Dornan v. Humphrey, 278 App. Div. roro, ro6 N.Y.S.2d 542 (4th Dep't 195I) after dismissal under the statute of limitations.

${ }^{25}$ N.Y. GeN. CORP. LAW $\S 64$ provides that the applicant for indemnity "shall be entitled to have his reasonable expenses, including attorneys' fees, actually and necessarily incurred . . . assessed against the corporation ... to the extent provided by section ... sixty seven. ..." Section 67 provides that if the applicant was successful in whole or in part or the action has been settled with court approval, "the Court shall grant such application in such amount as it shall find to be reasonable. . . ."

${ }^{28}$ Id. $\S 67$ (ii), (iii).

${ }^{28} \mathrm{Kr}$. REv. STAT. $\$ 271.375$ (1955). See also $i d$. $\$ 27$ r.I25 (II). 
The defendants themselves may not sit as judges in this director-judged determination, and if, for that reason, a quorum of disinterested directors cannot be obtained, the statute provides that a committee of three disinterested shareholders shall make the determination. This extra safeguard may have followed from an express enlargement of the indemnity in Kentucky to include, in addition to costs and expenses, any amount paid in settlement.

Having thus conferred a statutory right of indemnity on the insider, subject only to the reservations set forth in the statutes, these states (except Kentucky) then go on to provide that the statutory right is not exclusive and presumably may be enlarged by articles, bylaws, or directors' resolutions. ${ }^{29}$ Unnecessary confusion is introduced by these duplicate provisions. Pennsylvania and Wisconsin, for example, both provide that a corporation has power to indemnify insiders, that such "indemnification" is not exclusive, but that it exists only unless the articles provide otherwise. While this qualification appears to invite and honor articles denying indemnity, such articles might well be nullified by the statute conferring indemnity as a "right." Further, if a corporation should exercise its power to confer indemnity narrower in any respect than the statutory "right," the bylaw, article, resolution, or other document so narrowing the indemnity might be held ineffective. ${ }^{30}$

A second and more restrained approach to "correcting" the common-law decisions is made by the Delaware-type statutes, which give express power to the corporation to indemnify insiders not adjudged guilty of negligence or misconduct, but confer no right of indemnity in the absence of corporate action creating it. This approach comes nearest to constituting the "new look" on this subject, if only because it is fashionable. It was adopted, without significant modification, by Rhode Island ${ }^{31}$ in I948, and Maryland ${ }^{32}$ and Minnesota ${ }^{33}$ in I95I; and it was adopted as part of the completely revised codes of Oregon ${ }^{34}$ in 1953 , the District of Columbia ${ }^{35}$ in 1954 , $\mathrm{Ohio}^{36}$ and $\mathrm{Texas}^{37}$ in ${ }^{1955}$, Puerto Rico ${ }^{38}$ in 1956 , and Nevada ${ }^{30}$ and North Dakota $^{40}$ in 1957 . It has also been adopted, without significant change, as a part

\footnotetext{
${ }^{29}$ WIs. Stat. $\$ 180.04$ (14) (1955); N.Y. Gen. Corp. Law $\$ 63$; PA. Stat. ANN. tit. 15, $\$ 2852-410$ (Supp. 1956). The New York statute is again ambiguous as to whether a vote of sharcholders would be required to enact a bylaw or "resolution" providing indemnity.

${ }^{30}$ Wisconsin has vacillated on the need for two separate statutes. In 1949, it repealed the "right" statute, leaving the "power" provision. In 195I, it restored the "right" statute on the theory that indemnity, "if warranted, should be automatic and should not lie in the discretion of directors"; but it kept the "power" provision. WIs. STat. \$ r80.407; Revision Committee Note, x953 (1955).

${ }^{31}$ R.I. Pub. Laws (1948), c. 2154.

${ }^{32}$ MD. ANN. CODE art. 23, \$60 (r95 T).

${ }^{83}$ MinN. Stat. $\$ 301.09$ (7) (1953).

34 Ore. Rev. Stat. c. 57, 030 (I5) (Supp. 1955).

${ }^{35}$ D.C. CODE ANN. $\$ 29-904$ P (Supp. 1956).

${ }^{30}$ OHIo. Rev. COde ANN. \$ I701.13 (E) (Page Supp. 1956).

${ }^{37}$ Tex. Bus. Corp. ACt art. 2.02 (I6) (I956).

${ }^{38}$ P.R. LAws ANN. tit., \$ 202 (10) (Supp. 1956).

${ }^{39}$ Nev. Rev. Stat. $\$ 78.070$ (6) (Supp. 1957). The wording of this statute makes all powers conferred by statute, including the power to indemnify, subject to limitation in the articles of incorporation.

${ }^{40}$ N.D. Laws 1957 , c. 102, $\$ 4$ (15).
} 
of the Model Business Corporation Act of the American Bar Association. ${ }^{41}$ All these statutes read substantially like the Delaware statute, ${ }^{42}$ which is as follows:

Every corporation shall have power to...

Indemnify any and all of its directors or officers or former directors or officers or any person who may have served at its request as a director or officer of another corporation in which it owns shares of capital stock or of which it is a creditor against expenses actually and necessarily incurred by them in connection with the defense of any action, suit or proceeding in which they, or any of them, are made parties, or a party, by reason of being or having been directors or officers or a director or officer of the corporation, or of such other corporation, except in relation to matters as to which any such director or officer or former director or officer or person shall be adjudged in such action, suit or proceeding to be liable for negligence or misconduct in the performance of duty. Such indemnification shall not be deemed exclusive of any other rights to which those indemnified may be entitled, under any by-law, agreement, vote of stockholders, or otherwise.

As with many fashions, this approach covers a trouble, but does not eliminate it. It presupposes that the main fault in the common law was its refusal to find a corporate "power" to indemnify and that the way to remedy that fault is to make an express conferral of that power by statute. ${ }^{43}$ Actually, the fault of the common law was its failure to recognize and articulate rules for dealing with all the relevant circumstances out of which the indemnity claim arose, and the "no power" talk was only a manifestation of that failure. The Delaware-type statute, by directing itself to the manifestation rather than the cause of difficulty, slays what it thinks is the common-law dragon and leaves the field. The directors themselves then have a free hand to select the means for exercising the power: whether by management decision delegated to it by the directors, simple resolution of the directors, directorpassed bylaw, director-approved contracts with insiders, or otherwise. And they are left virtually free to dictate the terms on which indemnity will be granted. Further, the "nonexclusive" clause commonly found in the final sentence of these statutes appears to empower the directors to grant "other and further" indemnity or to give insiders "other rights" under bylaws or other action of directors or shareholders. Does this clause mean that the directors are thus empowered to indemnify insiders on terms other and further than those stipulated in the first part of the section, in which power to indemnify is given so long as negligence or misconduct is not adjudged? If not, what is the purpose of the "nonexclusive" clause? If so, is the effect any less than that insiders are enabled under the statute to adopt any means and terms of indemnity they wish? These questions have yet to be an-

¿I MOdEL Business Corporation ACT $\$ 4$ (o). A 1957 amendment recognizes the inconsistency in conferring a "power" and then Ieferring, in the last sentence of the statute, to "such indemnification." (Emphasis added.) The amendment reads, "... and to make any other indemnification which shall be provided for by the articles of incorporation, by-laws, agreement, vote of shareholders, or otherwise." See also note 20 supra.

${ }^{2}$ Del. Code Ann. tit. 8, $\$ 122$ (10) (x953).

${ }^{43}$ Most of the provisions cited in notes 3I-4I supra are contained in the chapter or section of the corporation statute which deals with the corporate powers. 
swered, ${ }^{44}$ but, meanwhile, this statutory solution may be said, in the wide discretion it gives to directors and in the ambiguity of its provisions, to contain as much possibility for a mischarge to the corporation as the common law contained for a mischarge to the insider.

The areas in which such a mischarge may be feared under the Delaware approach are best suggested by the statutory provisions of those states which have followed Delaware in part, but have made significant alterations. Three states, Connecticut, Maine, and Virginia, have foreseen situations in which a directors' resolution or a bylaw enacted only by directors, especially where many or most of them were defendants, might fail to protect the minority or corporate interests. It is arguable that this danger can be dealt with after it occurs by invoking the court's equitable powers to find a breach of the insiders' fiduciary obligations, although no case has yet tested the outer boundaries that equity would impose on the insiders' freedom to enact a bylaw permitted by the statute. These states prefer to recognize in advance and deal in the statute with the conflict of interest latent in a director-passed bylaw specifying indemnity terms. A bylaw in Connecticut ${ }^{45}$ or bylaw, article, or resolution in Maine, ${ }^{40}$ must be enacted by a majority vote of the shareholders. In Virginia, the statute is worded to require some indemnity bylaws to be approved by shareholders, but whether all would require approval is not clear. ${ }^{47}$

The main preoccupation in four other states which have modified the Delaware approach is with the possibility of mischarge to the corporation in settlement. Michigan makes a faint effort to prevent such a mischarge by denying the corporation the power to indemnify in matters "settled by agreement predicated on . . . liability [for negligence or misconduct]." ${ }^{38}$ Like the Wisconsin provision for determining guilt other than by adjudgment, this reservation provides no machinery for determining nonadjudged "liability" and is rather unrealistic in supposing that a settlement would contain a recital that it was based upon guilt or liability.

"4 A dictum in Mooney v. Willys-Overland Motors, Inc., 204 F.2d 888, 896 (3d Cir. 1953) suggests that the statute does not control every situation in which indemnification would be appropriate and quotes the "nonexclusive" clause of the statute and a similar "nonexclusive" clause in the bylaw of the corporation which contained indemnity language broader than the indemnity authorized by statute. Sce note 48 infra. Accordingly, a contract indemifying a director who was not a served party in the action was held valid. And in Sorenson v. The Overland Corporation, 242 F.2d 70 (3d Cir. 1957), an indemnity agreement under the same bylaw was held inapplicable, because the court thought that expenses in litigation arising out of defendant's successful defense of compensation arrangements made with him before he became an officer were incurred by him as an individual, "not because he was an officer."

${ }^{45}$ Conn. Gen. STst. $\$ 5$ r29 (1949). But this statute provides that the section shall not "affect any right to which [the insider] is entitled under any ... statute, by-law, agrcement, vote of stockholders or otherwise," without saying whether the agreement or other basis of indemnity (a director's resolution?) would require stockholders' approval.

${ }^{10}$ ME. Rev. Stat. ANn. c. 53, $\$ 24$ (I954). Maine has the same proviso as Connecticut referred to in note 45 stipra.

${ }^{17}$ VA. CODE ANN. $\$ 13 \cdot 1-3$ (n) (Supp. 1956). The statute gives a general power to indemnify by action not specified, but presumably it could be exercised in a bylaw. It then authorizes "other or further indemnity" by articles "or any by-law made by the stockholders."

${ }^{48}$ Mrch. CoMrp. Laws \$ 450.10 (I) (1948). 
Three states, New Jersey, Montana, and Missouri, deny power to indemnify unless the directors, as in Kentucky, make a determination regarding the fairness of the settlement and the nonadjudged culpability of the defendants. New Jersey provides that it shall be determined by the board, or in any other manner allowed by the articles or bylaws, that the defendant has "not in any substantial way been derelict in the performance of his duties as charged in such action." ${ }^{99}$ This determination would call, in many cases, for the possession by laymen directors of considerable sophistication in legal thought and language, extraordinary detachment from the views and interests of their insider-colleagues, and ability of the very highest judicial order.

In recognition of the judicial nature of the duty thus thrust on the directors, Montana permits them to "rely conclusively" on an opinion of independent legal counsel. ${ }^{50}$ Both Montana and Missouri add provisions that the director-determination shall not be participated in by the more obviously interested insider who is himself a defendant. In the event that his disqualification makes a quorum impossible, the determination is to be made, in Montana, by a committee of three disinterested shareholders, and in Missouri, by "a committee of three persons appointed by the shareholders." 51

These variations are interesting not so much for their cumbersomeness, as for their recognition of the danger, which the unvaried Delaware-type statute ignores, of allowing the directors a completely free hand in determining when and on what terms they or their colleague-directors or officers should be indemnified. Other problems of direct conflict in voting by insiders on such benefits as their own compensation, on contracts in which they have a direct or indirect interest, or on the rejection of corporate opportunities later taken by themselves, are recognized in corporation law. They are dealt with by such rules as the requirement of shareholder action or approval, subjection of the transaction in question to review by the court for fairness, or invalidation of the transaction altogether. Even in the absence of direct conflict, the dominant position occupied on many, if not most, boards by full-time employees of the corporation ${ }^{52}$ increases the probability of partiality toward the insider in an indemnity decision made by directors.

Even though many boards are not likely to want or need to test the limits of the "nonexclusive" clause by enacting "other and further" indemnity provisions going beyond the specifications in the first part of the statute, unlimited possibilities for doing so are left open by the statute; and at the very least, it is fair to assume that under bylaws enacted in the "new look" states, the insiders are almost invariably

${ }^{40}$ N.J. Stat. ANn. \$ 14:3-14 (Supp. I956).

${ }^{50}$ Mont. Rev. Codes ANn. $\$ 15-412$ (2) (1947). In Montana, as in Kentucky, the indemnification includes any amount paid in compromise. Cf. note 28 supra.

${ }^{21}$ Mont. Rev. Codes Ann. \$ 15-412 (2) (1947); Mo. Rev. Stat. \$35T.355 (I949).

as paur W. Dickson, Compensation and Duties of Corporate Directors (National Industrial Conference Board Studies in Business Policy No. 16 (1946), found that in r946, full-time paid officers represented a majority of the boards of half the 535 corporations surveyed. One of ten reported $100 \%$ officer boards. 
giving themselves a "right" to indemnity as unqualified as any that they can get by statute in a "right" state..$^{53}$

The third type of reaction to the common law is represented by California and North Carolina, the two remaining states which have enacted indemnity provisions. They may both be said to recognize more than the other states the variety of circumstances in each case that are relevant to preventing a mischarge either to the corporation or the insider. The California statute ${ }^{54}$ was the first of the two to be enacted and is simplest in its provisions: the whole matter is handed to the court for a completely ad hoc determination on each application, and no bylaw, article, resolution, or contract is permitted to have any control over the court's determination. This solution to the complexities of indemnity reflects confidence that the judge who hears the matter will accord proper weight to the various circumstances of the case, and that he is better able to do so than anyone else in an area where he is operating with uncontrolled discretion under a statute, uninhibited by past commonlaw mistakes. In a sense, this unique and drastically exclusive solution can be regarded as a form of turning back to, or starting over with, the common law.

The effect of the North Carolina statute ${ }^{55}$ is, like California's, to leave nothing to the insider and everything to the court in derivative actions in which the insider is partially or wholly successful. The language of "corporate power" is not employed. The insider in a derivative action in which, "or in the settlement" of which, he is partly or wholly successful is entitled to indemnification "for so much of his expenses . . . as the judge ... finds to be reasonable . . . if . . . the court finds that his conduct fairly and equitably merits such relief." A wholly or partly successful settlement for the defendant, while not defined, would presumably be one where less than the full amount of the relief sought in the complaint was provided by settlement.

'The North Carolina statute is the only one that recognizes that different equities might exist in nonderivative actions. It provides separate rules for indemnity in those cases, leaving less to the ad hoc discretion of the judge and giving more to the insider than does California, in the way of assurance that business-connected litigation expenses will be borne by the corporation as a matter of course. The insider is given a right of indemnity in nonderivative actions if wholly successful on the merits. If he were successful otherwise than solely on the merits, the statute leaves to the board of directors the determination whether to assume his expenses, but im-

${ }^{53}$ Of roo representative indemnity provisions adopted by corporations in I941, there was a "direct grant of indemnity" in ninety-two. The grant in ninety was not exclusive. In ninety-two cases, the primary basis for exception was a judgment of "derelict, liable, negligent, etc." See Bates and Zuckert, supra note 20 at appendix. For example, the Willys bylaw adopted in 1946, "purportedly in conformity with the Delaware statute," went beyond the language of the statute. The statutory exception of indemnity for negligence or misconduct appears in the bylaw as an exception for "wilful misfeasance, bad faith, gross negligence or reckless disregard. . . ." Mooney v. Willys-Overland Motors, 204 F.2d 888, 891, n. 5 (3d Cir. 1953). See note 44 supra.

54 Cal. CORP. Code $\$ 830$. For an analysis of this statute, see Ballantine, California's 1943 Statute as to Directors' Litigation Expenses, 31 Calf. L. REv. 515 (1943).

${ }^{55}$ N.C. GEN. STAT. $§ 55-19,55-20$, 55-21 (Supp. I955). 
poses no duty on the directors of making fact-determinations. When he is partly or wholly unsuccessful, he may, nevertheless, be paid if the holders of a majority of disinterested shares so vote at a meeting duly noticed to take such action.

The North Carolina solution, which is made exclusive by the statute, ${ }^{56}$ is, thus, the most detailed in recognizing the problems of avoiding a mischarge to either the corporation or the insider and in undertaking to provide rules for resolving them. ${ }^{57}$ It deserves careful consideration both by courts and legislatures in those states where no statute has been enacted, as well as in states, such as New York and Connecticut, where revision of the corporation statutes is reported now to be under way.

A consideration of statutes which affect the ultimate burden of litigation expenses would not be complete without reference to the "security-for-expenses" statutes, enacted in the five states of New York, Pennsylvania, Wisconsin, New Jersey, and California, ${ }^{58}$ under which insiders' expenses, including attorneys' fees, in derivative actions brought by "small" shareholders may be shifted from the indemnifying corporation to the plaintiff-shareholder. ${ }^{59}$ While the indemnification statutes look to the allocation of expenses as a matter of fairness or appropriateness, the security statutes, by imposing a risk on parties known to be in no position to assume it, allocate expenses as a device to deter the initiation of derivative actions by such parties.

As with indemnification, New York led the way. The language of the statute and the impetus for its enactment came from a report on derivative actions by a committee of the New York State Chamber of Commerce in $1944^{60}$ The premises and conclusions of that report, which are reflected in all but the California statute, were that many "nuisance" or "strike" actions had been brought solely or primarily for their settlement value to the shareholder or their fee value to his attorney, that an action initiated by the holder of shares too small in number to receive substantial benefit from a corporate recovery was probably such an action and was groundless in more cases than not, and that such actions ought to be deterred. ${ }^{61}$

The New York statute was, accordingly, enacted in 1944 to provide that in a derivative action begun by the holder of less than five per cent in number of the outstanding shares, unless their market value exceeded $\$ 50,000$, security must be

so Id. $\$ 55-\mathrm{xg}$.

${ }^{67}$ A statute which would undertake "more careful particularization" of the situations in which recovery would be allowed was recommended in a Comment, 40 CALIF. L. Rev. I04, II7-I8 (I952), before the North Carolina statute was enacted.

${ }^{68}$ The Maryland security-for-expenses provision excludes attorneys' fees. Rule 328b, Maryland Rules of Procedure, MD. ANN. Code I4x5 (Supp. I957).

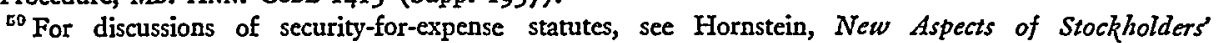
Derivative Suits, 47 Colom. L. Rev. I (1947); Should New York's "Security for Expenses" Act Be Amended? 2 Syracuse L. Rev. 37 (I95I); Pierce, Security for Expenses in Stockholder's Derivative Actions, in Current Trends in State Legrslation 388 (1952); Note, Security for Expenses Legislation -Summary, Analysis, and Critique, 52 Colum. I. Rev. 267 (1952).

${ }^{10}$ Frankitin S. Wood, Survey and Report Regarding Stockholders' Derivattve Sutrs (I944). For a criticism of this report, see Hornstein, The Death Knell of Stockholders' Derivative Szits in New York, 32 Calif. L. Rev. I23 (I944).

${ }^{a 1}$ Wood, op. cit. supra note 60 , at $21,24-25,33,36,47,76,112-17$. 
given for the reasonable expenses, including attorneys' fees, which might be incurred by the corporation and the individual defendants in the action. ${ }^{2}$ The statute further provides that the corporation "shall have recourse" to such security in such amount as the court shall determine upon termination of the action. Expenses of the insiders would always be incurred by the corporation and could thus be shifted to such a shareholder whenever the matter ended otherwise than upon "adjudgment for negligence or misconduct" of the individual defendants in the three states of New York, Pennsylvania, and Wisconsin, which have both indemnification-as-a-matterof-right statutes as well as security-for-expenses statutes. Pending the final outcome, the risk of payment would hang prohibitively over the head of any "small" sharcholder, as defined in the statute, who might consider initiating such an action alone or without being joined by others whose holdings aggregated the statutory minimum. ${ }^{63}$

The classification of shareholders who have to post security or pay defendants' fees was enlarged in the three states which soon adopted the New York statute. In 1945, New Jersey enacted a requirement that the holder have more than five per cent of the par or stated capital value of all the shares of every class in order to escape the security requirement. ${ }^{64}$ Pennsylvania $^{65}$ and Wisconsin ${ }^{66}$ removed the marketvalue exception, so that the holder of shares in excess of $\$ 50,000$ would still be required to post security if his holdings were less than the required percentage, which, in Wisconsin, was lowered to three per cent.

Since by far the greater number of the holders of corporate shares in the United States hold less than five per cent or even three per cent in number or value of the outstanding shares and less than $\$ 50,000$ in aggregate market value, ${ }^{07}$ the effect of these statutes in the commercially important states where they have been adopted has been to make the institution of derivative actions by most shareholders practically impossible. ${ }^{.8}$

Whatever may have been or may still be the abuses of derivative actions brought

${ }^{09}$ N.Y. GEN. CORP. LAW $\$ 6 \mathrm{I}-\mathrm{b}$.

${ }^{03}$ If the action is brought in the federal district court in New York, however, all joining plaintiffs must have owned their shares at the time of the transaction complained of, under the holding of Kaufman v. Wolfson, $x_{3} 6$ F. Supp. 939 (S.D.N.Y. 1955).

${ }^{6}$ N.J. Stat. ANN. \$ 14:3-15 (Supp. 1956).

os PA. Stat. ANn. tit. 12, 1322 (1953).

${ }^{\circ 0}$ WIs. STAT. \$ 180.405 (4) (1955).

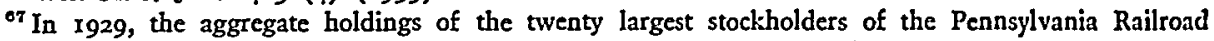
amounted to 2.7\%; of the American Telephone \& Telegraph Company, $4 \%$. AdoLph A. BERLE, Jn. AND Gardiner C. Means, The Modern Corporatton and Private Property 47 (1932). A survey of izo manufacturing corporations having assets of more than $\$ 100,000,000$ each in 1948 indicated that five out of six holders owned roo shares or less. Who Owns "Big Business"?, 87 Trusts \& Estatrs 5 (1948). "Random examples" of the market value of a $3 \%$ holding of any of nine Wisconsin corporations in 1956 showed the values to be from a minimum of $\$ 223,297$ to a maximum of $\$ 3,466,560$. Note, 1956 Wis. L. REv. 322, 325. See number of stockholders and amount of invested capital and assets of 500 largest United States industrial corporations. Fortune, July 1957, the Fortune directory supplement.

${ }^{\mathrm{B}}$ See Hornstein, New Aspects of Stockholders' Derivative Stits, 47 Corum. L. Rev. I, 5 (1947). 
without adequate grounds, alternatives to curbing these abuses by killing off the action do exist. One is suggested by the California statute. ${ }^{69}$ As with indemnification in that state, the matter is left to the supervision and discretion of the court. The statute provides that the court may fix security if the party moving for it establishes a probability in support of the ground that there is no reasonable probability of benefit to the corporation from the action of the security holders. ${ }^{70}$

A similar alternative is suggested by federal securities statutes. The Securities: Exchange Act of 1934, without assuming the probability that any action is an abuse, empowers the court, "in its discretion," to assess, or require security for, costs, including attorney's fees, of either party in an action for manipulation of securities: prices. ${ }^{71}$ This section has been interpreted in a stockholders' derivative action to: require the defendant moving for security to assume the burden of showing that the action is being abused. ${ }^{72}$ Likewise, the Securities Act of r933, as amended, gives the court discretion in any action under the Act to require either party to pay or give security for his opponent's expenses, including attorney's fees, if judgment isrendered against the party and if the court believes the unsuccessful action or defense"to have been without merit."73 And the Trust Indenture Act of I939 provides that "due regard to the merits and good faith of the claims or defenses" shall govern security and assessment in an action for liability for making a misleading statement ${ }^{74}$. and in security and assessment which may be required of holders of less than ten per cent in aggregate amount of indenture securities by agreement of parties to the indenture. ${ }^{78}$

Finally, the Federal Rule of Civil Procedure which requires court approval of any compromise or settlement of a derivative action, with notice to all shareholders, ${ }^{76}$ is an effective curb on the secret settlement or "pay-off" of the shareholderthat many writers have in mind when they use the term "strike" suit. ${ }^{77}$ The prevalence of such settlements in the I920's and early I930's undoubtedly gave rise to the federal rule, to the federal statutes, and to many of the abuses decried in the New York report. The adoption of such a rule, instead of a security-for-expenses provision, would leave any shareholder free, without undue risk, to protect the corporation's interests through a derivative action whenever such protection seemed neces-

${ }^{\circ 0}$ Cal. Corp. Code $\$ 834$.

70 For an analysis of the California statute, see Ballantine, Abuses of Stockholders Derivative Suits, How Far Is California's New "Security for Expenses" Act Sound Regulation?, 37 Calif. L. Rev. 399. (1949).

${ }_{71} 48$ STAT. 890, 15 U.S.C. $\$ 78 \mathrm{i}(\mathrm{e})$ (r952).

${ }^{73}$ Stella v. Kaiser, 83 F. Supp. 43 I (S.D.N.Y. 1949). See also Acker v. Schulte, 74 F. Supp. 683: (S.D.N.Y. r947).

${ }^{73}{ }_{48}^{8}$ STAT. 908 (1934), 15 U.S.C. $\$ 77 \mathrm{k}$ (e) (1952).

76 STAT. II76, I5 U.S.C. $\$ 77$ WWW (a) (1952).

${ }^{76} 53$ STAT. II72, I5 U.S.C. $\$ 77000$ (e) (1952).

${ }^{70}$ FED. R. Crv. P. 23 (c).

${ }^{77}$ See, e.g., the statement of Governor Edge, of New Jersey, as quoted by Ballantine, supra note 70,. at 402; Hornstein, Problems of Procedure in Stockholder's Derivative Suits, 42 Colum. L. REv. 574, 590 (1942); Milano, Security for Expenses in Shareholders' Derivative Suits, 5 N.Y.U. INTRA. L. REv.I96, 197 (1950); Note, I956 WIs. L. Rev. 322, 323. 
sary. The groundlessness of any such action, instead of being assumed, may best be demonstrated by a determined defense by insiders protected in their litigative efforts by appropriate indemnification. Groundlessness may then be dealt with in each case by the usual summary procedures for dealing with groundless actions and by discretionary power in the court to require security or assess costs and expenses. 